\section{Prospects of marine wealth entice Japan's biotechnologists}

Tokyo

JAPAN's Ministry of International Trade and Industry (MITI) is looking to the sea to solve two seemingly unrelated problems-the rundown of the nation's heavy industries and foreign complaints that Japan's research system is closed to outsiders.

From October, MITI, in collaboration with shipbuilding, steel, construction, panies, will start construction of two new marine research institutes as part of a ten-year project aimed at creating new industries for the extraction of 'fine chemicals' and other 'high-value-added' products from marine organisms. The birth of the new project accompanies a major reorganizaation of MITI-sponsored research which is intended to divert funds into the establishment of basic research institutes in the private sector that will be open to foreign researchers.

Under recently introduced legislation, the New Energy Development Organization (NEDO), set up jointly by MITI and private industry in 1980 to build pilot plants for tapping alternative energy resources, will be turned into the New Energy and Industrial Technology Development Organization. The new organization will have a much wider research and development role and will absorb several of MITI's big projects, such as the 'large-scale' and 'next-generation' industrial projects, as well the new 'fine chemicals from marine organisms' project. It will also initiate two other new projects: a high-speed 'elevator' in a disused coalmine shaft for manufacturing new materials in a weightless environment, and an ion-beam engineering research institute.

The new NEDO will use funds provided by industry and by national and local government. Additional interest-free loans will be derived from the sale of government shares in the now partly privatized telecommunications giant, Nippon Telegraph and Telephone (NTT). Dividends from governmentowned NTT shares are being used to support research centres such as MITI's Protein Engineering Research Institute but this is the first time that earnings from the NTT sale have gone into basic research

The research institutes will be 'rented out' to users-mainly researchers from the companies that help to establish the institutes. But under the new NEDO framework, special government subsidies can be given to encourage the institutes to include foreigners in the research teams. MITI hopes that this step petrochemical and biotechnology com- will help to counter Western complaints that Japan's research system is closed. be built in Shimizu, near Tokyo, and in Kamaishi on the north-east coast of the main island of Honshu. The ports of Kamaishi and Shimizu were selected partly because they allow access to two major ocean currents-the cold Oyashio current and the warm Kuroshio curheavy industrial plants in the two cities has provided land and harbour facilities. Nippon Steel recently closed its last blast furnace in Kamaishi, and Toa Nenryo Kogyo, a large oil refiner, has land available from a former plant in Shimizu. Both companies are key backers of the new institutes.

Six thousand million yen (about $\$ 50$ million) has been allocated for the institutes' construction in the second half of fiscal 1988 (which begins in October). And MITI hopes to pour another Y 15,000 million ( $\$ 120$ million) into the project over the next ten years with a similar amount from private industry.

One of the participating companies, Suntory Ltd, a major distiller that has diversified into biotechnology, has been conducting marine research since 1979. Suntory has its own research vessel and
The two marine research institutes will rent-and partly because the closure of agents, from corals collected from reefs in Australia, Palau and Okinawa. But MITI officials say they will not include research on drugs in their proposals to the Ministry of Finance, as this would encroach upon the territory of the Ministry of Health and Welfare. Similarly, fish Ministry of Agriculture, Forestry and Fisheries, but the project aims to develop 'fine chemicals' such as barnacleresistant paints. David Swinbanks MITI is not the only ministry to bring 'biotechnology' projects to areas suffering from industrial decay. The Ministry of Agriculture, Forestry and Fisheries, under the auspices of BRAIN (Bio-oriented Technology Research Advancement Institution), another organization financed through the privatization of NTT, is developing aquaculture using tanks in a recently closed coal mine in Nagasaki prefecture. And the same organization, with the support of Nippon Steel and Hitachi Zosen, one of Japan's largest shipbuilding concerns, has set up the Iwate Biomass Institute to develop techniques to convert softwood from Japan's flagging forestry industry into feed for cattle. The mere mention of the word biotechnology sends local governments clamouring for these government projects, despite the fact that it will probably be years before they pay off in terms of new jobs. has been searching for new drugs, particularly anticancer and antihypertension research will remain in the domain of the

\section{Rock holds key to mineral riches}

A rLEet of ships has set sail from Yokohama to save a vital piece of Japanese territory-two lumps of rock protruding less than a metre out of the south-west Pacific ocean. Okinotorishima, lying $6,800 \mathrm{~km}$ south of Tokyo, is a respectable little island of about five by two kilometres at low tide. But at high tide only two rocks are left sticking about $\mathbf{7 0}$ centimetres above the sea. If these are washed away Japan will lose about $\mathbf{4 0 0 , 0 0 0}$ square kilometres of its 200 -mile exclusive economic zone and with it all rights to fishing and minerals in

the area; the surround. High-tide at Okinotorishima (Kyodo Photo).

ing sea abounds with tuna and bonito, and | ing rocks of Okinotorishima to form a cobalt-rich crusts have been found on the adjacent deep-sea floor.

Five years ago there were four rocks above high tide level. But erosion has reduced these to two propped up on fragile columns of rock. And as the island lies in the typhoon belt they could be swept away at any moment. The 22,000 -ton Sun-

\section{IMAGE UNAVAILABLE FOR COPYRIGHT REASONS} will be reinforced with concrete. Automated meteorological observation equipment is expected to be installed on the island. Salvage of the "island" will take three years and cost about 30,000 million yen ( $\$ 240$ million).

David Swinbanks imosu Ace, mother ship of a four-vessel fleet, left Yokohama on April 22 laden with iron tetrapods, concrete, several small boats and two helicopters. Tetrapods will be laid around the two remain- 